\section{Duck Egg Allergy in an Adult Patient Without Allergy to Chicken Egg}

Alcántara Villar $\mathrm{M}^{1}$, Palacios Colom $\mathrm{L}^{1}$, Anaya Anaya $\mathrm{S}^{1}$, Bustamante Orvay $\mathrm{L}^{2}$, Jimeno Nogales $\mathrm{L}^{2}$

${ }^{1}$ Unidad Alergología. Complejo Hospitalario de Jaén, Jaén, Spain ${ }^{2}$ Departamento I+D ALK-Abelló, Spain, Madrid, Spain

J Investig Allergol Clin Immunol 2019; Vol. 29(3): 245-246 doi: $10.18176 /$ jiaci.0370

Key words: Uncommon food allergy. Duck egg. Ovalbumin.

Palabras clave: Alergia alimentaria infrecuente. Huevo de pato. Ovalbúmina.

Egg is a basic ingredient in our diet because it provides essential nutrients of high biological value that are easily assimilated by the human body. Duck egg allergy is an uncommon food allergy that has been commonly associated with allergies to other types of egg, usually chicken [1].

We present a case of food allergy after ingestion of duck egg in an adult patient with no previous allergy to chicken egg.

The patient was a 25 -year-old woman with a medical history of urticaria to dog dander who experienced abdominal pain, diarrhea, and loss of consciousness within 60 minutes after ingestion of a fried duck egg. She tolerated hen egg with no problems. No symptoms of rhinitis or asthma were reported.

Skin prick tests were performed with commercially available extracts of common inhalant allergens (house dust mites, molds, animal dander, and pollens) and hen egg proteins (egg white, egg yolk, ovalbumin, and ovomucoid) (Leti). Prick-prick testing was performed with fresh homemade uncooked white and yolk from duck egg (Anas domesticus) according to the Dreborg and Foucard method [2].

Specific and total IgE were determined using ImmunoCAP (ThermoFisher Scientific) to hen egg proteins (yolk, white, ovalbumin, and ovomucoid) according to the manufacturer's instructions, with negative results (ImmunoCAP $<0.35 \mathrm{kU} / \mathrm{L}$ )

Fresh homemade extracts of white and yolk of duck egg were prepared in phosphate buffer at $10 \%(\mathrm{wt} / \mathrm{vol})$ and kept for 90 minutes at $4^{\circ} \mathrm{C}$ with magnetic shaking. They were then centrifuged, the resultant supernatant was filtered through a $0.2-\mu$ m membrane, and glycerin was added up to $50 \%$ before use. Commercial extracts of ALK from hen's egg were also used.

The extracts and the molecular weight markers were analyzed using glycine SDS-PAGE (acrylamide concentration, $16 \%$ ) under nonreducing conditions. The extract proteins separated by SDS-PAGE were transferred onto nitrocellulose membranes as described by Towbin et al [3]. Immunoblotting of IgE-binding protein was achieved by enhanced chemiluminescence according to the manufacturer's instructions (ECL-Amersham Bioscience). As negative controls, the blots were also incubated with dilution buffer.

Skin prick tests were positive for pollens of grass, olive, Plantago, cypress, and dog dander and negative to the

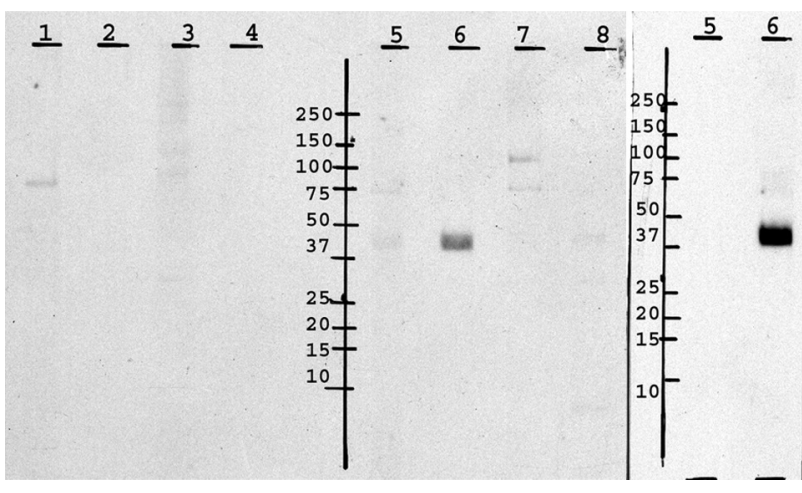

Figure. IgE-immunoblotting of egg extracts. Lane 1, hen egg white + c. negative. Lane 2, hen egg white + patient serum. Lane 3, hen egg yolk + c. negative. Lane 4, hen egg yolk + patient serum. Lane 5, duck egg white + c. negative. Lane 6, duck egg white + patient serum. Lane 7, duck egg yolk + c. negative. Lane 8, duck egg yolk + patient serum. Molecular weight markers are indicated in the center $(10,15,20,25$, $37,50,75,100,150$, and $250 \mathrm{kDa}$ ).

remaining inhalant extracts and hen's egg. Prick-prick testing was only positive to duck egg white, with a wheal measuring $22 \mathrm{~mm}$ in diameter.

The Figure shows the result of IgE Immunoblotting for the different egg extracts.

Duck egg allergy is an uncommon allergy. Allergy to egg is associated with different species, although 2 cases of specific allergy to duck egg in patients with no hen egg allergy have been reported. In both, a lysozyme and ovalbumin were identified as the responsible allergens [4,5]. In the case presented in this study, the protein detected by immunoblotting has a molecular weight that suggests that ovalbumin could be the allergen responsible for the allergic reaction. The patient's $\mathrm{IgE}$ recognized this protein in duck egg but not in hen egg. These findings seem to indicate that the patient's IgE can recognize specific epitopes of duck egg ovalbumin.

\section{Funding}

The authors declare that no funding was received for the present study.

\section{Conflicts of Interest}

The authors declare that they have no conflicts of interest.

\section{References}

1. Savage JH, Matsui EC, Skripak JM, Wood RA. The natural history of egg allergy. J Allergy Clin Immunol. 2007 Dec;120(6):14137.

2. Dreborg S, Foucard T. Allergy to apple, carrot and potato in children with birch pollen allergy. Allergy. 1983;38:167-72.

3. Towbin H, StaehelinT, Gordon J. Electrophoretic transfer of proteins from polyacrylamide gels to nitrocellulose sheets: procedure and some applications. Proc Natl Acad Sci USA. 1979 Sep; 76(9):4350-4. 
4. Anibarro B, Seoane FJ, Vila C, Lombardero M. Allergy to eggs from duck and goose without sensitization to hen egg proteins. J Allergy Clin Immunol. 2000;105:834-6.

5. Fernández Cortés S, Fernández García A, Armentia Medina A, Pineda F. Duck Egg Allergy in a Patient Who Tolerates Hen's Eggs. J Investig Allergol Clin Immunol. 2013;23(2):125-40.

Manuscript received August 21, 2018; accepted for publication January 4, 2019.

Manuel Alcántara Villar

Unidad Alergología

Complejo Hospitalario de Jaén

Avenida Ejército Español 23007 Jaén

E-mail: manuel.alcantaravillar@gmail.com 